This document is the accepted manuscript version of the following article:

Guo, H., Özparpucu, M., windeisen-Holzhauser, E., Schlepütz, C. M., Quadranti, E., Gaan, S., ... Burgert, I. (2020). Struvite mineralized wood as sustainable building material: mechanical and combustion behavior. ACS Sustainable chemistry and Engineering. https://doi.org/10.1021/acssuschemeng.0c01769

\title{
Struvite Mineralized Wood as Sustainable Building Materials: Mechanical and Combustion Behavior
}

Huizhang Guo*1,2,\#, Merve Özparpucu, ${ }^{3, \#}$, Elisabeth Windeisen-Holzhauser ${ }^{3}$, Christian M. Schlepütz ${ }^{4}$, Elia Quadranti ${ }^{1}$, Sabyasachi Gaan ${ }^{5}$, Christopher Dreimol, ${ }^{1,2}$ Ingo Burgert* ${ }^{1,2}$

1. Wood Materials Science, ETH Zürich, Stefano-Franscini-Platz 3, 8093 Zürich, Switzerland.

2. Wood \& Cellulose Materials, Empa - Swiss Federal Laboratories for Materials Science and Technology, Überlandstrasse 129, 8600 Dübendorf, Switzerland.

3. Wood Research Munich, Technical University of Munich, Winzererstraße 45, 80797 Munich, Germany.

4. Swiss Light Source, Paul Scherrer Institut, Forschungsstrasse 111, 5232 Villigen PSI, Switzerland.

5. Advanced Fibers, Empa - Swiss Federal Laboratories for Materials Science and Technology, Lerchenfeldstrasse 5, 9014 St. Gallen, Switzerland.

*Email: huguo@ethz.ch

iburgert@ethz.ch

Abstract: A more extensive use of wood can reduce the environmental and climatic impact of the building industry. However, flammability limits the application of wood in multi-story and high rise timber buildings. Struvite mineralization has been shown to be a green solution for fire-resistant timber, but the influence of struvite minerals on the mechanical and gluing properties of wood as well as the combustion behavior have not been studied yet. In this work, we investigate the mechanical properties of mineralized wood by compression, bending, and tension tests as well as the gluing properties by tensile shear tests. Evolved gas analysis using GC/MSD system is applied to determine the thermal decomposition behavior of the mineralized wood, and Double shot analysis reveals volatile components of mineralized wood during the thermal decomposition process. The results show that the struvite mineralization treatment is a bulk modification technique that improves the fire resistance of wood. The mineralization can significantly influence the thermal decomposition behavior of wood, which results in an enhanced char formation. This char layer is a fire barrier that slows down the heat and oxygen penetration. The heat penetration rate of wood panels fabricated with mineralized wood is $0.6 \mathrm{~mm} / \mathrm{min}$ during the cone calorimeter test, which is half of that of the wood panels fabricated with native wood. Transverse strength and stiffness under compression were improved, whereas mechanical loading in the longitudinal direction revealed similar or slightly decreased strength and stiffness. The mineralization had a minor impact on the gluing properties of solid wood. Wood mineralization by struvite may enable the more extensive use of wood in the construction sector as a substitute to less eco-friendly building materials.

Keywords: Wood materials, mechanical analysis, mineralization, fire resistance, combustion 


\section{Introduction}

The building industry uses a great number of raw materials that require high energy consumption and/or cause high $\mathrm{CO}_{2}$ emissions during processing, such as steel, aluminum, and concrete, ${ }^{1}$ which dominates the current building materials market. ${ }^{2}$ Wood has an ecological advantage over steel and concrete as a building material, ${ }^{3}$ being renewable, and storing nearly one ton of $\mathrm{CO}_{2}$ per cubic meter. ${ }^{4}$ However, the use of wood, especially in high-story timber structure, is limited due to the inherent flammability of wood. ${ }^{5-6}$

To change the combustion behavior, wood products can be treated with fire retardants. ${ }^{5,7}$ Halogenated compounds based on chlorine or bromine are effective flame retardants, which can terminate the chemical reaction, scavenge free radicals and increase char formation in combustion. However, their environmental and health risks impact their application. ${ }^{8}$ Metal hydrates, which are typically aluminum- or magnesium-based, are also common fire retardants. ${ }^{9-11}$ Their endothermic decomposition can absorb heat, and the released water vapor in the decomposition process can dilute the flammable gases, but char formation cannot be promoted. Boron-based flame retardants, such as borax-boric acid, are generally good char producers, which induce acid-catalyzed dehydration reactions during decomposition and reduce the effective heat release. ${ }^{12}$ Phosphorus compounds, typically nitrogen-containing, are not only the char promoters but also the radical scavengers to suppress the spread of the fire. These fire retardants can leach from wood and typically leave behind a significant environmental footprint and health concerns. ${ }^{13}$ Novel wood modification methods are under focus to increase the fire safety of timber products without spoiling wood as a sustainable and environmentally friendly building material. Densification was not only applied to increase the mechanical properties of wood, ${ }^{14}$ but also leaded to highly compact laminated wood surfaces that can block the oxygen infiltration, promote pyrolysis reactions and enhance char formation. ${ }^{15}$ Mineralization leads to wood-inorganic hybrid materials, for example, the clay impregnated wood, ${ }^{16} \mathrm{CaCO}_{3}$ mineralized wood, ${ }^{17-18}$ and $\mathrm{Mg}$-Al-layered hydroxide coated wood. ${ }^{11}$ Cement-bonded wood wool boards ${ }^{19}$ were developed as natural fiber and inorganic hybrid building materials. Wang et al. bonded waste wood particles with magnesia-phosphate cement (MPC) to produce cement bonded particleboards. ${ }^{20-21}$ However, calcined magnesia is required for the preparation of MPC paste via acid-base reaction ${ }^{22}$ and magnesia calcination is a highly energy demanding process and high $\mathrm{CO}_{2}$ emisson.

Wood cell walls are composed of three principal polymeric materials, including cellulose, hemicellulose, and lignin. ${ }^{23}$ The heavily cross-linked structure of lignin makes contributions to the overall char yield in native wood, while cellulose and hemicellulose mainly decompose to volatile pyrolysis products that are responsible for flaming combustion. ${ }^{24}$ Char formation has a 
significant effect on the combustion behavior of wood. A dense char layer acts as a heat and mass transport barrier, which inhibits volatiles released from the decomposed wood and oxygen penetration from the air. An efficient fire retardant has typically the capability to change the thermal decomposition process of wood, which promotes the cross-linking reactions of the dehydrate cellulose and repolymerization of levoglucosan to yield aromatic structures, becoming graphitic carbon structures during the pyrolysis process. Thus, the fire retardant can also inhibit the formation of combustible components responsible for the ignition of the wood. Stevens et al. investigated the influence of phosphorus compounds on the decomposition of wood, which indicated that all of the alkyl- and phenylchlorophosphorus compounds decreased the temperature of the pyrolysis peak (from $350{ }^{\circ} \mathrm{C}$ to $\max .240{ }^{\circ} \mathrm{C}$ ) and increased the char formation (from $25 \%$ to $\max .54 \%)^{25}$

In our recent research, we have developed a bio-inspired method to mineralize wood with Struvite $\left(\mathrm{MgNH}_{4} \mathrm{PO}_{4} \cdot 6 \mathrm{H}_{2} \mathrm{O}\right)$ for fire resistance. ${ }^{26}$ Struvite decomposes at a lower temperature than wood, which absorbs heat, releases non-flammable gas, and results in amorphous $\mathrm{MgHPO}_{4}$, which promotes insulating char formation. Struvite is an eco-friendly material that can be gained from wastewater and used as a plant fertilizer. Although Struvite has been demonstrated as a promising fire retardant for wood, ${ }^{27}$ its effect on wood mechanical properties (stiffness and strength) is unknown. A reliable structural material, which can be standardized, is essential for construction purposes. Furthermore, timber products, such as glue-laminated timber and cross-laminated timber, strongly rely on the bond quality of wood and adhesives. ${ }^{28-29}$ Finally, the effect of Struvite minerals on the combustion behavior of the wood substrate has not been studied yet.

\section{Experimental details}

Materials. Anhydrous magnesium sulfate (199 $\left.\mathrm{g}, \mathrm{MgSO}_{4}, \geqslant 99.5 \%\right)$, potassium phosphate monobasic $\left(\mathrm{KH}_{2} \mathrm{PO}_{4}, 99 \%\right)$, and ammonium hydroxide solution $\left(\mathrm{NH}_{4} \cdot \mathrm{OH}, 25 \%\right)$ were purchased from Sigma, Chemie Brunschwig AG, VWR International AG, respectively.

Wood sample preparation. Norway spruce (Picea abies) was used as the wood material. The wood samples were cut into different sizes according to the specific requirements of mechanical analysis or fire test. Consider the property deviation of wood, "pair tests" were used. Hence, twin wood samples were cut in matched positions, and one was used for mineralization treatment, and the other was used as a reference. All samples were conditioned at $20^{\circ} \mathrm{C}$ and $65 \%$ relative humidity. The weight of each wood sample was recorded before mineralization. The dimensions of the wood samples used for the mechanical tests are shown in Figure $\mathrm{S} 1$ in the supporting information. Sample sizes and densities of native and mineralized wood are shown in Table S1. 
Mineralization. The wood mineralization method was adopted from our former publication. ${ }^{26}$ In a typical procedure, the wood samples were loaded into a desiccator, which was pumped down and controlled under vacuum between $15 \mathrm{mbar}$ and $25 \mathrm{mbar}$ for one hour. The aqueous precursor solution was prepared by dissolving $199 \mathrm{~g}$ of $\mathrm{MgSO}_{4}$ and $225 \mathrm{~g}$ of $\mathrm{KH}_{2} \mathrm{PO}_{4}$ into $1.5 \mathrm{~L}$ of water. The precursor solution was sucked into the desiccator until all of the wood samples were covered. The desiccator was kept under vacuum for another half hour. After that, the vacuum was released, and the samples were kept at ambient pressure for one hour. The impregnation process was repeated twice. The vacuum impregnated samples were removed into a plastic box and then fumigated by ammonia in a sealed box for twelve hours. Ammonia gas was introduced for fumigation by putting a flask containing $100 \mathrm{~mL}$ ammonium hydroxide solution in a sealed plastic box. After that, $40{ }^{\circ} \mathrm{C}$ oven-drying for 24 hours was applied to remove excess ammonia to avoid smell of ammonia of the struvite mineralized wood. The mineralization process was repeated twice to obtain sufficient mass gains. All samples were conditioned at $25{ }^{\circ} \mathrm{C}$ and $65 \%$ relative humidity. The weight of each mineralized wood sample was recorded, and the mass gain resulting from mineralization was calculated. To investigate the influence of ammonia fumigation alone, some wood samples were only impregnated with water and then fumigated as described above. An additional experiment was conducted to verify that the mineralization is also applicable for large scale wood modification in an acceptable time. Wood panels with a dimension of $250 \mathrm{~mm}$ (Longitudinal direction) $\times 170 \mathrm{~mm}$ $\times 50 \mathrm{~mm}$ were used for mineralization. The mass gain of the larger size wood panels was calculated to $\sim 80.6 \%$, which is similar to the small size samples used for mechanical analysis.

\section{Mechanical analysis.}

Compression tests were performed with a universal testing machine following the DIN 52192 norm for the radial and tangential directions and according to the DIN 52185 norm in the longitudinal direction. For the compression tests, the samples were cut to a size of $60 \mathrm{~mm} \times 20 \mathrm{~mm}$ $\times 20 \mathrm{~mm}$. The respective samples with $60 \mathrm{~mm}$ in longitudinal, tangential and radial direction were loaded along longitudinal, tangential and radial direction, accordingly The radial and tangential tests were terminated when a maximum deformation of $5.5 \%$ was reached. The longitudinal tests were terminated after failure when the force declined by $10 \%$ of the maximum force. The number of the mineralized wood specimens used for the analysis was 19 in the radial direction, 21 in the tangential direction, and 19 in a longitudinal direction, respectively. The same number of references (native wood) in each loading direction were tested, respectively.

Three-point bending tests were conducted according to the DIN 52186 norm. The wood samples were cut into pieces with dimensions of $230 \mathrm{~mm} \times 12 \mathrm{~mm} \times 12 \mathrm{~mm}$ in the longitudinal $\times$ tangential $\times$ radial direction. The load was applied in the tangential direction. The number of mineralized 
wood specimens used for the bending test was 25 . The number of native wood specimens used as reference was 25 .

Tension tests were conducted according to the DIN 52188 norm, but with smaller sample dimensions. The wood samples were cut into dog bone shape with a size of $230 \mathrm{~mm}$ in the longitudinal direction, $3 \mathrm{~mm}$ in the tangential direction, and $15 \mathrm{~mm}$ in the radial direction at the edge of the sample while $8 \mathrm{~mm}$ in the radial direction at the middle of the sample. The number of mineralized wood specimens used for the tension test was 17 . The number of references was the same.

The tensile shear test was conducted based on the DIN EN 302-1 norm. Wood panels with a dimension of $170 \mathrm{~mm} \times 100 \mathrm{~mm} \times 5 \mathrm{~mm}$ in longitudinal $\times$ radial $\times$ tangential direction were used. The panels were glued by Polyurethane (PUR) or Phenol-Resorcinol-Formaldehyde (PRF) adhesives, respectively. After gluing, samples with $2 \mathrm{~cm}$ in width (along radial direction) were cut out from the boards. Two notches were cut with a depth of $5 \mathrm{~mm}$ from each side of the sample. The two notches had a distance of $10 \mathrm{~mm}$. As a result, the force will transfer from one panel to the other through the glue-line area of $200 \mathrm{~mm}^{2}$ in the middle. The number of mineralized wood specimens used for the tensile shear test was 12 . The same number of native wood specimens were used as reference.

\section{Cone calorimeter analysis}

Cone calorimetry (Fire Testing Technology Instrument, East Grinstead, UK) analysis was carried out according to the ISO 5660-1:2002 norm to assess the HRR (heat release rate) and dynamic SRR (smoke release rate) for specimens exposed in a horizontal orientation to controlled levels of irradiance with an external igniter (conical heater). The igniter provided a constant heat flux of 50 $\mathrm{kW} \cdot \mathrm{m}^{-2}\left(\mathrm{~T} \approx 750^{\circ} \mathrm{C}\right)$. Wood panels with a dimension of $120 \mathrm{~mm} \times 120 \mathrm{~mm} \times 5 \mathrm{~mm}$ in longitudinal $\times$ radial $\times$ tangential were used. The wood panels were glued into the five-layer cross-laminated structure using Polyurethane (PUR, LOCTITE HB S709 Purbond). The edge of the structure was cut away, which resulted in a CLT panel with a dimension of $100 \mathrm{~mm}$ in length and width and 26 $\mathrm{mm}$ in thickness. Thermocouples were installed on the surface and the bottom of the CLT panel to measure the heat penetration.

\section{Evolved Gas Analysis (EGA)}

The EGA was performed with a double shot pyrolyzer Py-2020iD (Frontier Laboratories) coupled to a 5975C Series GC/MSD system (Agilent Technologies). A total of 24-28 $\mu \mathrm{g}$ of samples was put into a stainless steel cup (Eco cup, Frontier Laboratories) to be inserted into the pyrolysis furnace. Three measurements were done on each of the two native wood samples $(n=6)$, whilst three measurements were done on each of the three mineralized wood samples $(n=9)$. The samples were 
heated continuously from $50{ }^{\circ} \mathrm{C}$ up to $700{ }^{\circ} \mathrm{C}$ with a heating rate of $10{ }^{\circ} \mathrm{C} / \mathrm{min}$, whereas the GC oven and the inlet are held isothermally at $300{ }^{\circ} \mathrm{C}$. The evolved gases were transferred via a deactivated stainless steel EGA column $(2.5 \mathrm{~m} \mathrm{x} 0.15 \mathrm{~mm})$ to the MS detector without chromatic separation.

\section{Double Shot Analysis (DSA)}

Double Shot Analysis (DSA) allows sequentially determining the volatile components of a sample. In the first thermal desorption (TD) stage, the samples $(0.09-0.1 \mathrm{mg}$, taken by a razor blade) were heated to $240^{\circ} \mathrm{C}$ for $2 \mathrm{~min}$ in the pyrolysis oven (Py-2020iD, Frontier Laboratories). The resulting evaporated volatiles are trapped at the beginning of the GC column $(30 \mathrm{~m} \times 0.25 \mathrm{~mm}$ x $0.25 \mu \mathrm{m}$, VF-17ms, Agilent Technologies) and analyzed via GC/MS (5975C Series GC/MSD system, Agilent Technologies). After the TD, the residual sample was pyrolyzed (Py) at $350^{\circ} \mathrm{C}$ for $0.2 \mathrm{~min}$. The emerging pyrolysis products were then analyzed with GC/MS . For both thermal desorption and pyrolysis steps, $\mathrm{GC}$ oven was set to $50^{\circ} \mathrm{C}$ with a holding time of $1 \mathrm{~min}$, then heated to $300{ }^{\circ} \mathrm{C}$ with a heating rate of $10{ }^{\circ} \mathrm{C} / \mathrm{min}$, finally, it was kept at $300{ }^{\circ} \mathrm{C}$ for $4 \mathrm{~min}$. The mass spectrometer was operated in EI mode (70 eV, scanning $\mathrm{m} / \mathrm{z} 40-700)$. The MS transfer line temperature was $250{ }^{\circ} \mathrm{C}$. The MS ion source temperature was fixed at $230{ }^{\circ} \mathrm{C}$ and the MS quadrupole temperature at $150^{\circ} \mathrm{C}$. Two replicates were analyzed from both native and mineralized wood samples, and three measurements were performed for each of the replicates $(n=6$, for both native and mineralized wood).

\section{X-ray tomography}

The failure zones of the wood samples were analysized by X-ray tomographic microscopy at the TOMCAT beamline X02DA of the Swiss Light Source, Paul Scherrer Institute. Radiographic projections of the samples were acquired over an angular range of 180 degrees at an X-ray energy of $10 \mathrm{keV}$. The edge-enhanced absorption images of the sample were converted to visible light by a $17 \mu \mathrm{m}$ thick LuSiO5:Tb scintillator placed $6 \mathrm{~mm}$ downstream of the sample rotation center. These visible-light images were magnified by an optical microscope (Optique Peter, France) onto the imaging chip of a pco.Edge 5.5 sCMOS camera with a pixel size of $6.5 \mu \mathrm{m}$ (PCO AG, Germany), using 10x magnification objectives, resulting in effective pixel sizes of $0.65 \mu \mathrm{m}$. Tomographic volume data sets were reconstructed using the Paganin propagation-based phase retrieval method with a $\delta / \beta$ ratio of 200 to enhance the contrast between air, wood, and mineral structures. 


\section{Results and discussion}

The influence of struvite mineralization on the mechanical performance of wood was determined by pair analysis in compression, tension, and bending. Table 1 summarizes the average values of strength and Young's modulus from the mechanical analysis of mineralized wood and native wood.

Table 1. Mechanical test results $(\sqrt{ }$ significant difference, $\times$ no significant difference $)$

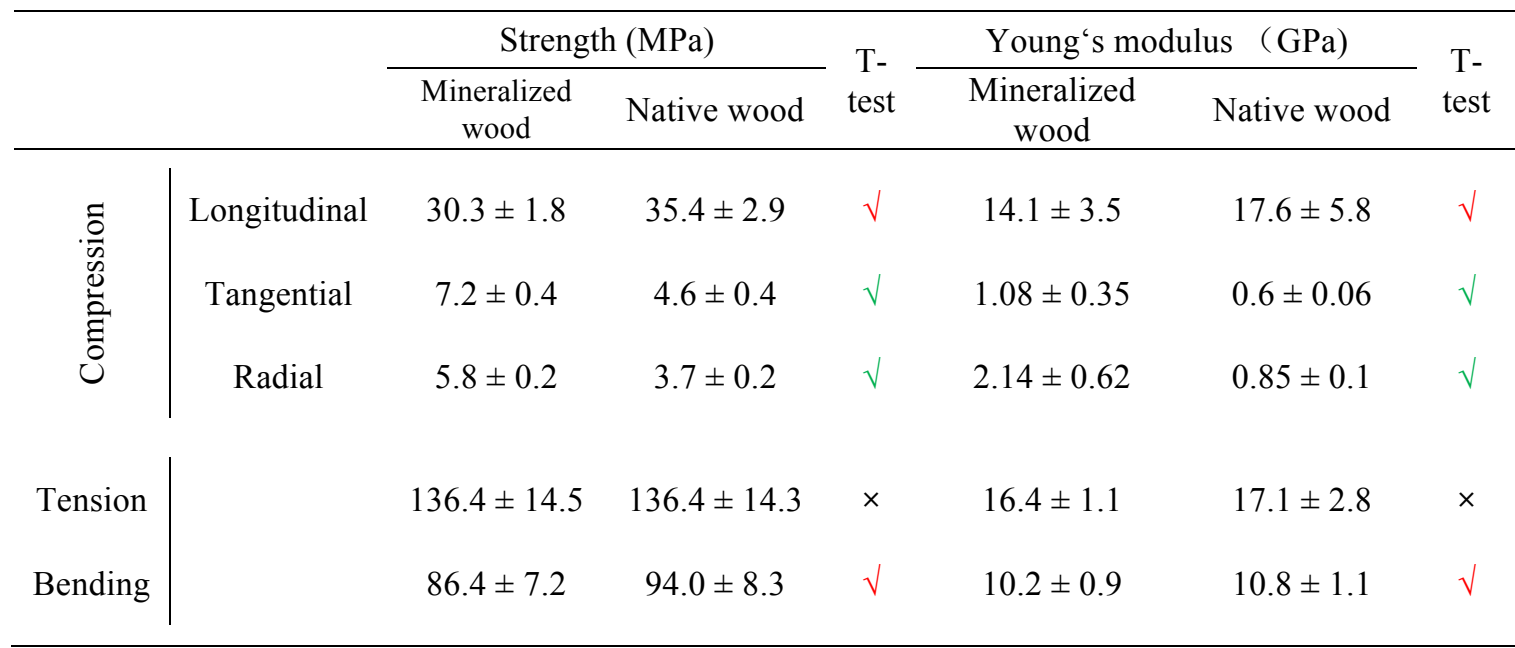

The mineralization increased the density of the longitudinal compression test samples from 412 $\mathrm{kg} / \mathrm{m}^{3}$ to $754 \mathrm{~kg} / \mathrm{m}^{3}$ ( $+83 \%$, Figure S2). In the longitudinal direction, a slight decrease in both strength and Young's modulus of the mineralized wood was observed (Table 1 and Figure S3). To individually investigate the influence of ammonia fumigation, we studied the compression properties of wood samples only impregnated by water and then fumigated by ammonia. The results show that the ammonia fumigation (without mineralization) does not influence the longitudinal compression strength or Young's modulus (Figure S8). The mineralization increases the density of the tangential compression test samples from $440 \mathrm{~kg} / \mathrm{m}^{3}$ to $815 \mathrm{~kg} / \mathrm{m}^{3}(+85 \%$, Figure S4), and the density of the radial compression test samples from $428 \mathrm{~kg} / \mathrm{m}^{3}$ to $889 \mathrm{~kg} / \mathrm{m}^{3}$, respectively $(+84 \%$, Figure S6). As a result, we observed significant increases in compression strength and Young's modulus of the mineralized wood when the loading is applied in the tangential or radial direction, respectively (Table 1, Figures S5 and S7). Contrary, ammonia fumigation in the absence of the salt solution decreases the tangential and radial compression strength (Figure S9, S10 and Table S2).

Phase-contrast X-ray imaging was used as a nondestructive microstructure analysis method to study the influence of struvite mineralization on the mechanical properties of wood in the compression test in more detail. Microstructures shown of mineralized samples in Figure 1 indicate that the initial step responsible for the failure in longitudinal compression tests is a buckling of the L-oriented cell walls along the radial direction, ${ }^{30}$ followed by delamination at the boundary between earlywood and latewood. We also observe buckling along the radial direction in the failure region of native wood (Figure 2d-f). However, no delamination of the boundary between earlywood and latewood 
was observed. Ammonia fumigation alone did not change the mechanical properties of wood under longitudinal compression. The results reveal that the mineral particles or the precursor solution influence the cell boundary, which reduces the interaction among the individual wood tracheids and leads to the reduced strength of mineralized wood in longitudinal direction under compression.
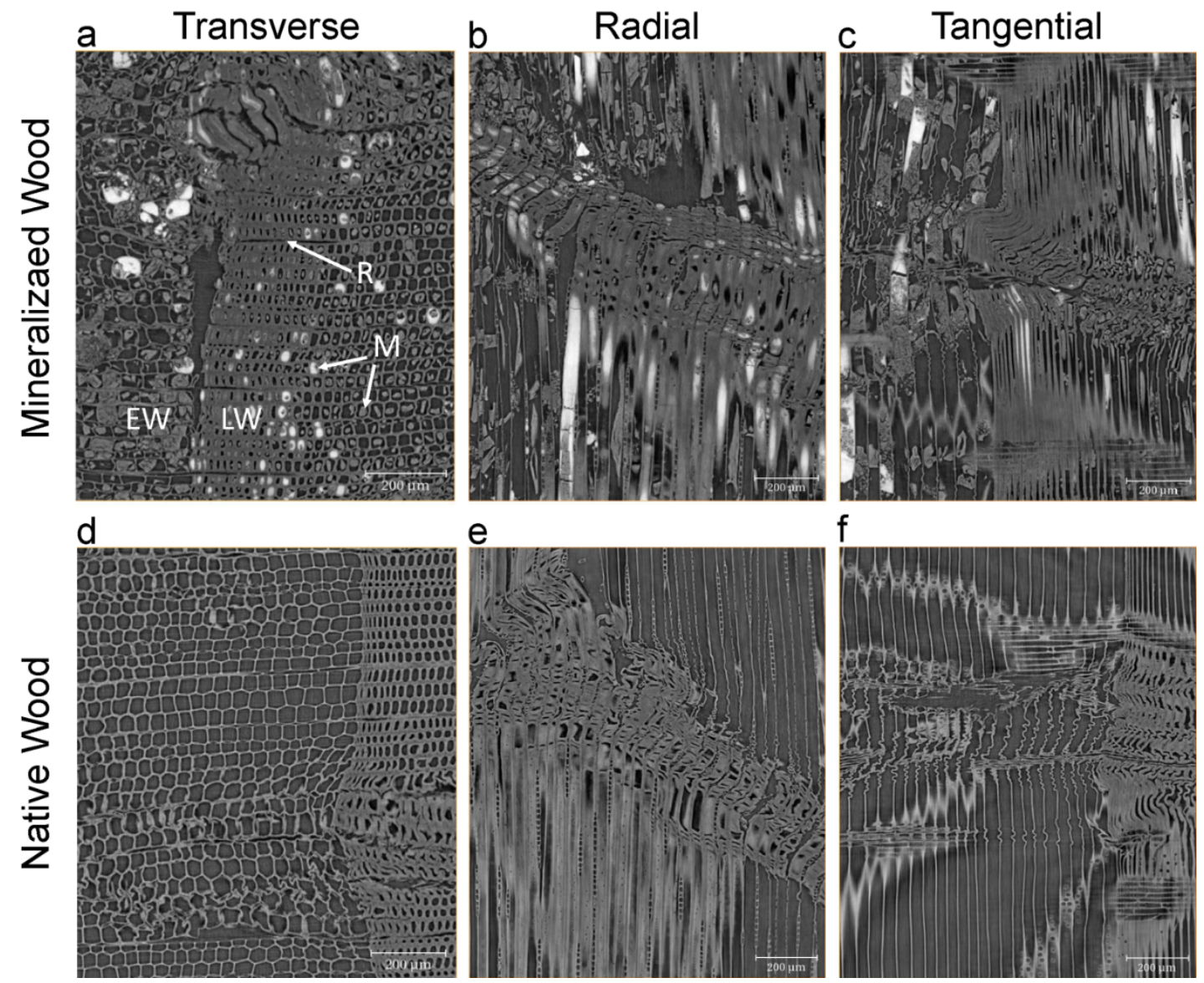

Figure 1. The computed X-ray tomography slices of a transverse section (a), a radial section (b) and a tangential section (c) of struvite mineralized wood, as well as the transverse section (d), radial section (e) and tangential section (f) of native wood after the compression test along the longitudinal direction. R: wood ray; M: struvite mineral; LW: latewood; EW: earlywood.

In the tangential direction, the partly crushing of earlywood cells results in compression failure (Figure 2e-f), which continues along the tangential direction, and causes the buckling of the growth ring as shown in Figure 3d. The compressive behavior of the native wood as observed in this work is similar to that observed by Bodig and Jayne. ${ }^{31}$ Although the ammonia fumigation weakened the strength of wood perpendicular to the fiber direction (Figure S9 and S10), the mineral particles in the wood lumina have a severe stabilizing effect. The earlywood has wider lumina and hence, the volume ratio of the struvite mineral particles is higher in the earlywood than in the latewood. The compression failure of the mineralized wood occurs via the bending of the latewood (Figure $3 \mathrm{a}$ and b), which is different from the native wood. The struvite mineralized wood has higher compression Young's modulus and strength along the tangential direction than the native wood (Table 1 and 
Figure 4). In the radial direction, the compression failure occurs in native wood by the crushing of earlywood, which continues with slippage along the annual ring and densification of earlywood (Figure $3 \mathrm{~d}$ to $\mathrm{f}$ ). Due to the stabilizing effect of the struvite minerals in the earlywood, a different failure behavior was observed in the struvite mineralized wood (Figure 3a-c). The compression failure of the mineralized wood resulted from the bending of latewood along the radial direction. In the end, the wood fibers crack along the rays. Typical native wood failure is due to the deformation of earlywood, while the mineralized wood failure is due to the deformation of latewood. The enhanced radial compression modulus and strength of struvite mineralized wood compared to their native counterparts attribute to the different failure mechanisms.
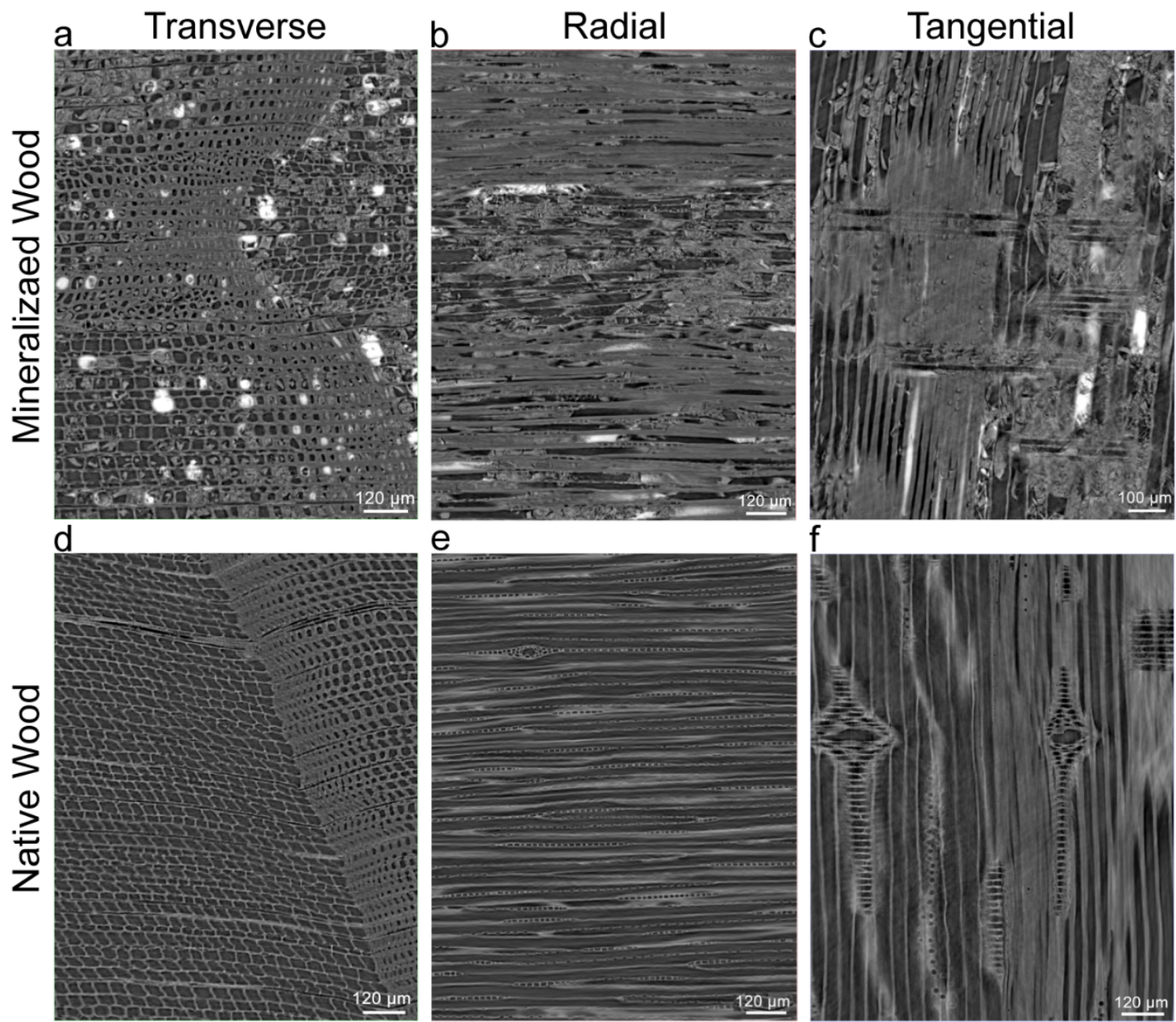

Figure 2. The computed X-ray tomography images of a transverse section (a), a radial section (b) and a tangential section (c) of struvite mineralized wood, as well as the transverse section (d), radial section (e) and tangential section (f) of native wood after the compression test along tangential direction. 

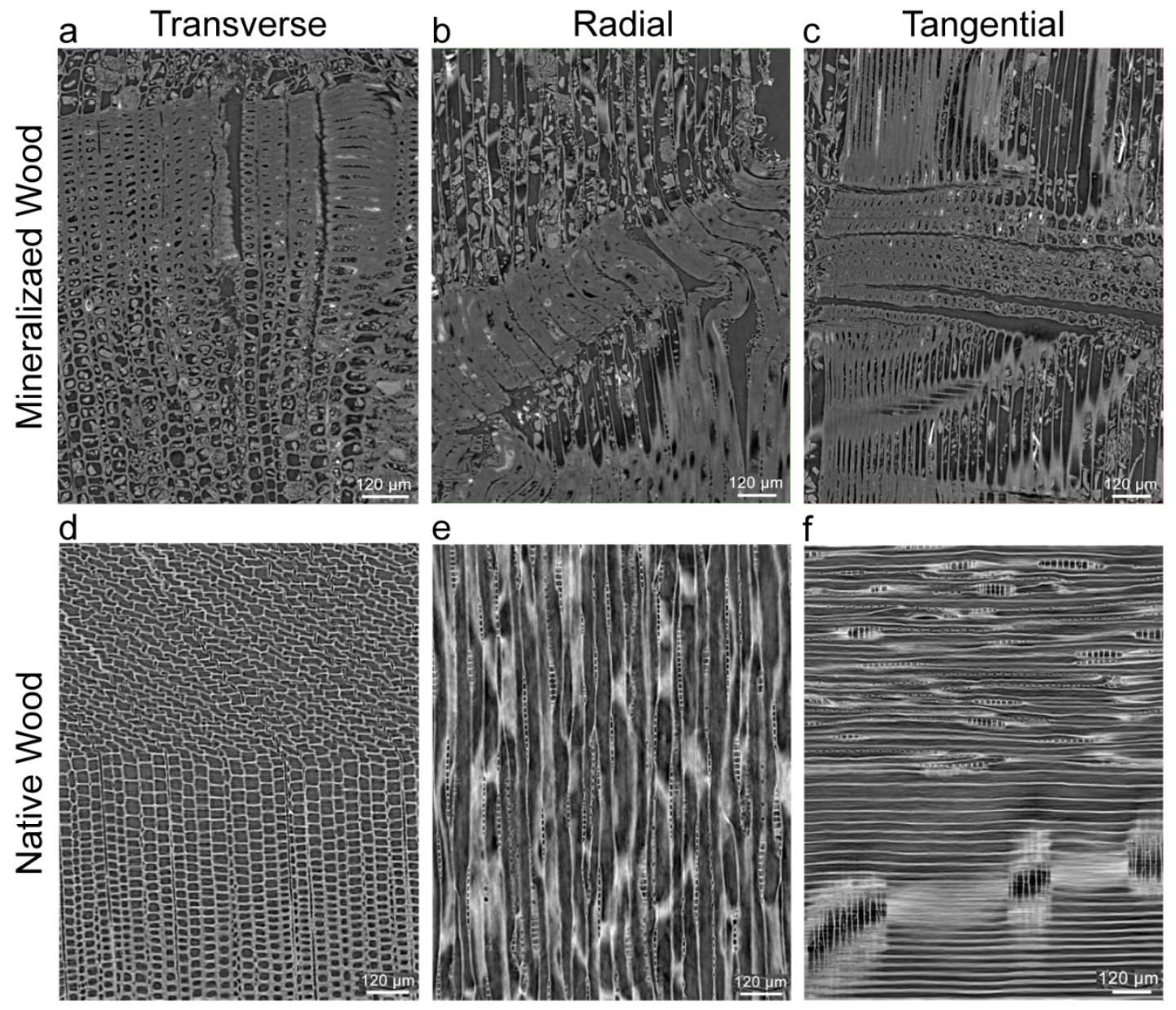

Figure 3. The computed X-ray tomography images of a transverse section (a), a radial section (b) and a tangential section (c) of struvite mineralized wood, as well as the transverse section (d), radial section (e) and tangential section (f) of native wood after the compression test along the radial direction.

The mechanism responsible for the failure of native and mineralized wood under compression in the tangential and radial direction is a collapse of wood tracheids and delamination. The minerals formed in the cell lumina have a stabilizing effect perpendicular to the grain because they increase the resistance against cell wall crushing, which results in greater compression strength and Young's modulus. The increase of compressive strength and elastic modulus in compression in radial and tangential direction is in contrast to the reduction of mechanical properties in longitudinal direction. The representative stress-strain diagrams of the tangential compression tests show a significantly different behavior between native and mineralized wood (Figure S5). The curve of the native wood has a brittle behavior and exhibits a wider elastic region while the curve of the mineralized wood indicates a more ductile behavior with a smaller elastic region and a significant strengthening (strain hardening) before failure. The representative stress-strain diagrams of the radial compression test samples also show a different behavior of native and mineralized wood (Figure S7). The curve of the native wood exhibits a wider elastic region with a constant plastic region once the yield point 
has been reached. The curve of the mineralized wood has a smaller elastic region and exhibits a strengthening (strain hardening) in the plastic region right before the failure.

The results of tensile test in longitudinal direction are presented in Table 1 and Figure 4. In the fibre direction, tensile modulus and tensile strength of mineralized and native wood showed no significant difference according to the T-test. The results reveal that the mineralization cannot reinforce the wood cell or the wood cell interface. Three-point bending tests were conducted by applying the external load in the tangential direction of the samples. The paired T-test indicated a significant decrease in the three-point bending strength of mineralized wood. The bending strength has an average reduction of $8.1 \%$, and the bending Young's modulus has an average decrease of $5.6 \%$ by the mineralization (Figure 4). During the three-point bending test, the upper part of the wood sample is under compression, while the lower part of the sample is under tension. A failure on the compression side of the wood specimen typically occurs at first during a three-point bending test. Therefore, the reduced three-point bending strength may be explained as a consequence of the loss of mechanical performance under longitudinal compression.

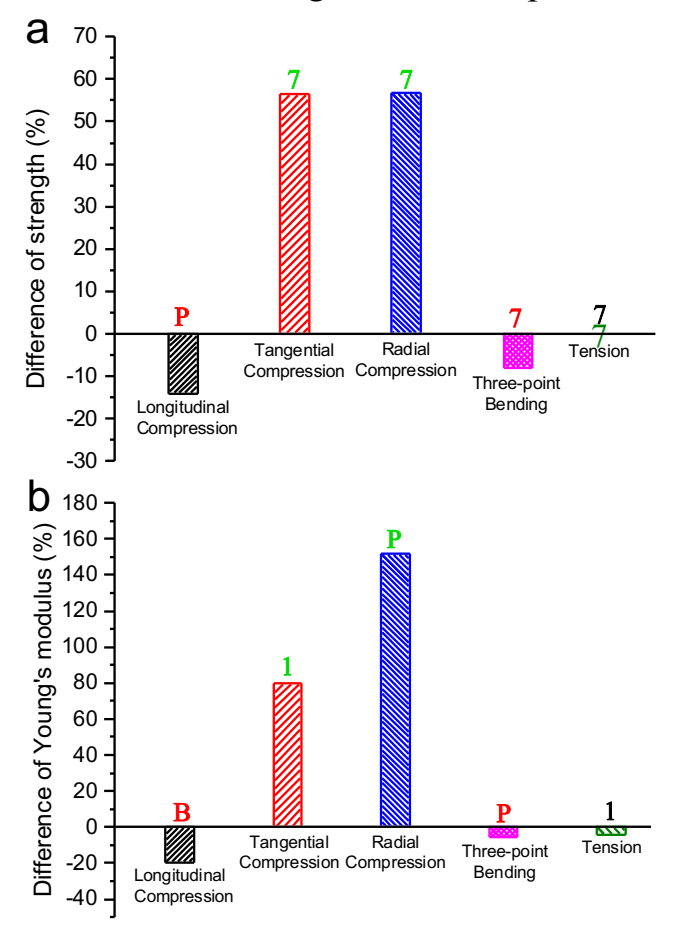

Figure 4. Comparison of strength (a) and elastic modulus (b) between native and mineralized wood. Wood bonding plays an essential role in modern timber structures. We compared the tension shear strength of mineralized wood with native wood, which was glued together with two commercially available adhesives (1C-polyurethane (PUR) and Phenol-Resorcinol-Formaldehyde (PRF)), respectively. The results shown in Table 2 demonstrate that the native and mineralized wood samples bonded by PUR had a similar tensile shear strength when the failure happened in the wood. 
Table 2. Tension shear test results

\begin{tabular}{|c|c|c|c|c|c|}
\hline & & \multicolumn{2}{|c|}{ Wood failure } & \multicolumn{2}{|c|}{ Glue failure } \\
\hline & & $\begin{array}{l}\text { Strength } \\
(\mathrm{MPa})\end{array}$ & $\begin{array}{l}\text { Specimen } \\
\text { number }\end{array}$ & $\begin{array}{l}\text { Strength } \\
(\mathrm{MPa})\end{array}$ & $\begin{array}{c}\text { Specimen } \\
\text { number }\end{array}$ \\
\hline \multirow{2}{*}{ PUR } & $\begin{array}{l}\text { Mineralized } \\
\text { wood }\end{array}$ & $5.8 \pm 1.3$ & 9 & $9.74 \pm 0.7$ & 3 \\
\hline & Native wood & $5.6 \pm 0.7$ & 12 & $\mathrm{~N} / \mathrm{A}$ & 0 \\
\hline \multirow{2}{*}{ PRF } & $\begin{array}{l}\text { Mineralized } \\
\text { wood }\end{array}$ & $8.6 \pm 1.2$ & 8 & $9.2 \pm 1.3$ & 4 \\
\hline & Native wood & $5.1 \pm 0.5$ & 4 & $9.3 \pm 1.2$ & 8 \\
\hline
\end{tabular}

We also observed some failure in the adhesive with an average tension shear strength of 9.74 MPa. In the specimens bonded with PRF, it was found that the mineralized wood fractured with an average shear strength of $8.6 \mathrm{MPa}$, while for native wood fracture at a much lower shear strength of 5.1 $\mathrm{MPa}$ was measured. For shear strength higher than $9 \mathrm{MPa}$, the failure only took place in the glue line. In summary, the results indicate that the mineralization did not affect the gluing properties of the spruce wood.

Evolved Gas Analysis (EGA) on wooden materials provides information on thermal degradation areas of the main constituents, cellulose, hemicelluloses, lignin, and extractives or additives. Such information is valuable for the specific adjustment of pyrolysis temperatures concerning the corresponding samples. Therefore, before the detailed chemical analysis of wood-pyrolysis products by Py-GC/MS, total ion chromatogram (TIC) of volatiles evolved from wood samples at different temperatures were measured by EGA. As shown in Figure 5, TIC was significantly different between the native and mineralized wood. For native wood, the maximum abundance of decomposition species appears at $350{ }^{\circ} \mathrm{C}$ with a shoulder at around $300{ }^{\circ} \mathrm{C}$. However, in the mineralized wood, the maximum abundance temperature was found around $235-250{ }^{\circ} \mathrm{C}$ and a second maximum was observed around $340{ }^{\circ} \mathrm{C}$. Furthermore, the abundance of evolved gases also showed significant differences between the native and mineralized wood; the max abundance of evolved gases was proximately $83 \%$ higher in native wood $\left(269878 \pm 451\right.$, at $\left.350{ }^{\circ} \mathrm{C}\right)$ compared to mineralized wood $\left(46405 \pm 133, \sim 240{ }^{\circ} \mathrm{C}\right)$. 


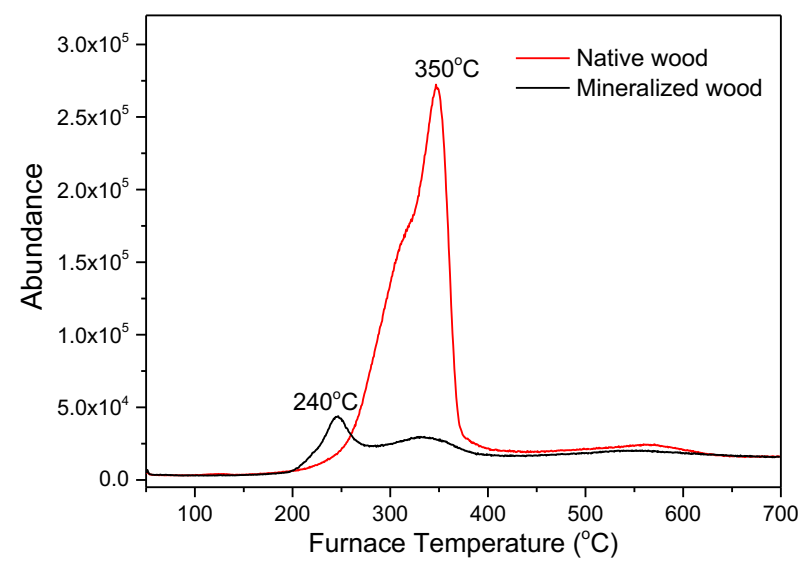

Figure 5. EGA thermograms of native and mineralized wood.

As EGA results led to two different thermal temperature profiles of the native and mineralized wood, for a detailed analysis of the volatile compounds, a double shot analysis (DSA) was performed in two steps. In the first step, samples were heated to $240{ }^{\circ} \mathrm{C}$ to evaluate the decomposition products formed at an early stage. Then, in the second step, the residual samples were pyrolyzed at $350^{\circ} \mathrm{C}$ to simulate the products formed during the main stage decomposition of the wood.

The comparison of the thermal desorption gas chromatograms at $240{ }^{\circ} \mathrm{C}$ between the native and the mineralized wood is given in Figure 6. In line with EGA thermograms, in the mineralized wood, a drastic increase in the abundance of the total volatiles was found. A very large peak of levoglucosenone ( $\mathrm{LGO}, \mathrm{C}_{6} \mathrm{H}_{6} \mathrm{O}_{3}$ ) was observed at $9.41 \mathrm{~min}$., in addition to some minor other pyrolysis products of carbohydrates such as furfural at $3.71 \mathrm{~min}$. and 1,4:3,6 dianhydro- $\alpha \mathrm{D}-$ glucopyranose (DGP) at $10.88 \mathrm{~min}$., whereas in the native wood, the peaks were hardly seen and can be assigned to the pyrolysis of the aromatic compounds (phenol at $5.88 \mathrm{~min}$ and 3-(4hydroxy-3-methoxyphenyl)-2-propenal at $17.3 \mathrm{~min}$ ). Moreover, the maximum abundance (based on peak heights) in native wood was $95 \%$ lower than the maximum abundance in the mineralized wood. Notably, the variation within the native and mineralized wood was consistent to a high extent as seen from the individual chromatograms in the supplementary information (Figure S12 and S13).

Previous studies indicate that levoglucosan $\left(\mathrm{C}_{6} \mathrm{H}_{10} \mathrm{O}_{5}\right)$ is one of the main pyrolysis products of the carbohydrates (polymeric hexoses) ${ }^{32}$ and it is mostly proposed as an intermediate product forming levoglucosenone (LGO) by loss of two water molecules. ${ }^{33}$ However, there are also studies arguing that the LGO could be directly formed from the pyrolysis of the hexose unit without involving levoglucosan (LG) as an intermediate. ${ }^{34}$ Although the formation of the mechanism of LGO is still not clear, it has been often showed that the transformation of the LG to LGO occurs under acid-catalyzed pyrolysis, ${ }^{33,35-36}$ and even by catalytic fast pyrolysis of 
biomass, LGOs are produced in low yield. ${ }^{37}$ Therefore, there have been various studies aiming at increasing the LGO yield. ${ }^{38-42}$ For example, in one of the studies, the wood was treated with phosphoric acid, and this led to a $30 \%$ increased yield of LGO after pyrolysis at $375^{\circ} \mathrm{C} .{ }^{36}$

According to our results, in the mineralized wood, after thermal desorption at $240{ }^{\circ} \mathrm{C}$, LGO was found as the single major product (besides some minor furfural and anhydrous-glucopyranose), Struvite crystals $\left(\mathrm{MgNH}_{4} \mathrm{PO}_{4} \cdot 6 \mathrm{H}_{2} \mathrm{O}\right)$ are composed of equimolar content of $\mathrm{Mg}^{2+}, \mathrm{NH}_{4}{ }^{+}$, and $\mathrm{PO}_{4}{ }^{3-}$ and its thermal decomposition is well studied in the literature. ${ }^{43-44}$ The decomposition starts around $110{ }^{\circ} \mathrm{C}$ and continues stepwise, however, in the first step, the formation of $\mathrm{MgHPO}_{4}$ is usually completed before $\sim 180{ }^{\circ} \mathrm{C}$, which is at a lower temperature than the decomposition of wood. In the second step, $\mathrm{MgHPO}_{4}$ is decomposed to the final compound of which is most likely related to the interaction of the organic compounds with struvite mineral $\mathrm{Mg}_{2} \mathrm{P}_{2} \mathrm{O}_{7}\left(190-725{ }^{\circ} \mathrm{C}\right) .{ }^{26,} 44$ Therefore, during the pyrolysis experiments (at $240{ }^{\circ} \mathrm{C}$ and $350{ }^{\circ} \mathrm{C}$ ), $\mathrm{MgHPO}_{4}$ is expected to be a dominant decomposition product of the struvite mineral. Our experimental data indicate the potential conversion of $\mathrm{MgHPO}_{4}$ to phosphoric acid $\left(\mathrm{H}_{3} \mathrm{PO}_{4}\right)$ by hydrolysis during thermal desorption, which in turn provides an acidic catalyzed pyrolysis environment and explains the formation of levoglucosenone in the mineralized wood.
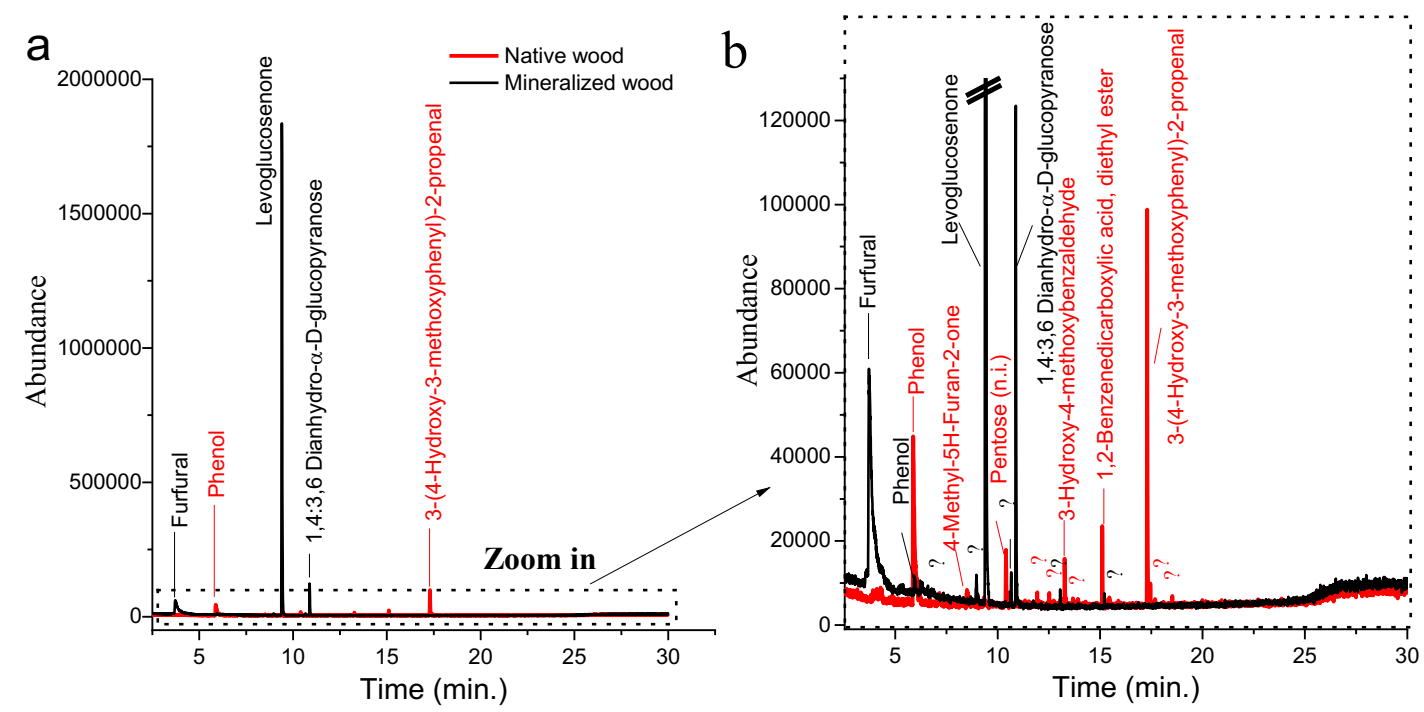

Figure 6. a) Total ion chromatogram of native and mineralized wood after thermal desorption at $240{ }^{\circ} \mathrm{C}, \mathrm{b}$ ) a zoom into the chromatograms in lower abundance levels (//: large peak is cut off in Y-axis to display the details of moderate and minor peaks, ?: not identified (n.i.), minor compounds which their MS spectra are not specific enough to allow for the identification of these substances accurately.)

The gas chromatograms, which were plotted stacked in the $\mathrm{Y}$-axis, of one of the representative native and mineralized wood samples pyrolyzed at $350{ }^{\circ} \mathrm{C}$ are given in Figure 7 . By increasing the pyrolysis temperature from $240{ }^{\circ} \mathrm{C}$ to $350^{\circ} \mathrm{C}$, no major changes are found in the pyrolysis 
products of the mineralized wood (Figure 6-7). In the mineralized wood, a higher abundance of LGO was observed, and it was still found to be the main pyrolysis product. There is also an increase observed in the abundance of the other primary sugar pyrolysis products such as furfural and 1,4:3,6 dianhydro- $\alpha$-D-glucopyranose at $350{ }^{\circ} \mathrm{C}$ compared to thermal desorption at $240{ }^{\circ} \mathrm{C}$. In addition to these components, levoglucosan, and a phenolic compound (2methoxy-4-propylphenol, originated from lignin) were seen in the gas chromatogram of mineralized wood (Figure 7), and the abundance of levoglucosan showed some variability within the mineralized wood (see Figure S15-16).

The chromatogram of native wood showed much more pronounced changes by increasing the temperature from $240{ }^{\circ} \mathrm{C}$ to $350{ }^{\circ} \mathrm{C}$ (Figure 6-7). In particular, it showed a higher number of pyrolysis products, as shown in Figure S17. The first five major peaks indicate methoxyphenol (Lg, lignin-derived), eugenol ( $\mathrm{Lg})$, phenol (Lg), anhydrohexose(Ps, polysaccharide derived) and cyclopentanol (Ps), respectively. The assignments of the rest of the peaks in the native wood are given in the supplementary information (Table S3 and Figure S14). Nevertheless, all compounds found in the native wood were typical pyrolysis products of sugars and aromatic structures, and in line with Py-GC/MS results of spruce in the literature. ${ }^{45}$ For a semiquantitative comparison of the pyrolysis products, an integration of the peak areas was applied with a threshold of " $\geq 5 \%$ " of the largest peak area. When the integration areas of the peaks compared between mineralized and native wood, approx., $78 \%$ larger area (as an indication of volatile abundances) was found in the native wood (see Table S3 and S4).

These results confirm EGA thermograms and show the drastic influence of mineralization on the pyrolysis products. The decomposition of struvite continues to promote the formation of levoglucosenone at $350{ }^{\circ} \mathrm{C}$ as well and results in a completely different amount and type of pyrolysis products in the wood. In a very recent study, the formation mechanism of LGO in phosphoric acid-catalyzed fast pyrolysis of cellulose was studied both theoretically and experimentally. According to this study, after depolymerization of cellulose to $\mathrm{LG}, \mathrm{H}_{3} \mathrm{PO}_{4}$ alters competitiveness of the secondary pyrolytic pathways of LGO formation, and due to the relative weak steric hindrance of acid assisted transition states, activation free energies of the elementary reactions decreases, which in turn, LGO formation is facilitated. ${ }^{46}$ During decomposition of struvite, such a similar mechanism is supposed to be present in the pyrolysis environment.

Although LGO cannot be a part of the char constituents as a monomer due to its relatively low molecular mass $(126.11 \mathrm{~g} / \mathrm{mol})$ and boiling point $\left(254.40{ }^{\circ} \mathrm{C}\right.$. $\left.@ 760.00 \mathrm{~mm} \mathrm{Hg}\right)$, its highly 
dehydrated chemical structure most likely contributes to the char formation process which provides a fire resistance in the mineralized wood.

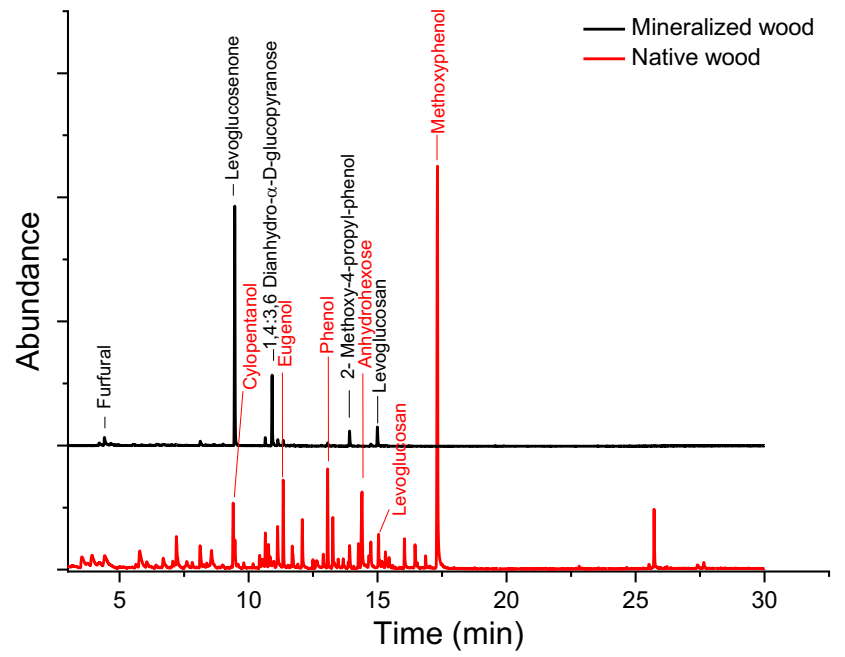

Figure 7. Total ion chromatogram of the native and mineralized wood pyrolyzed at $350{ }^{\circ} \mathrm{C}$.
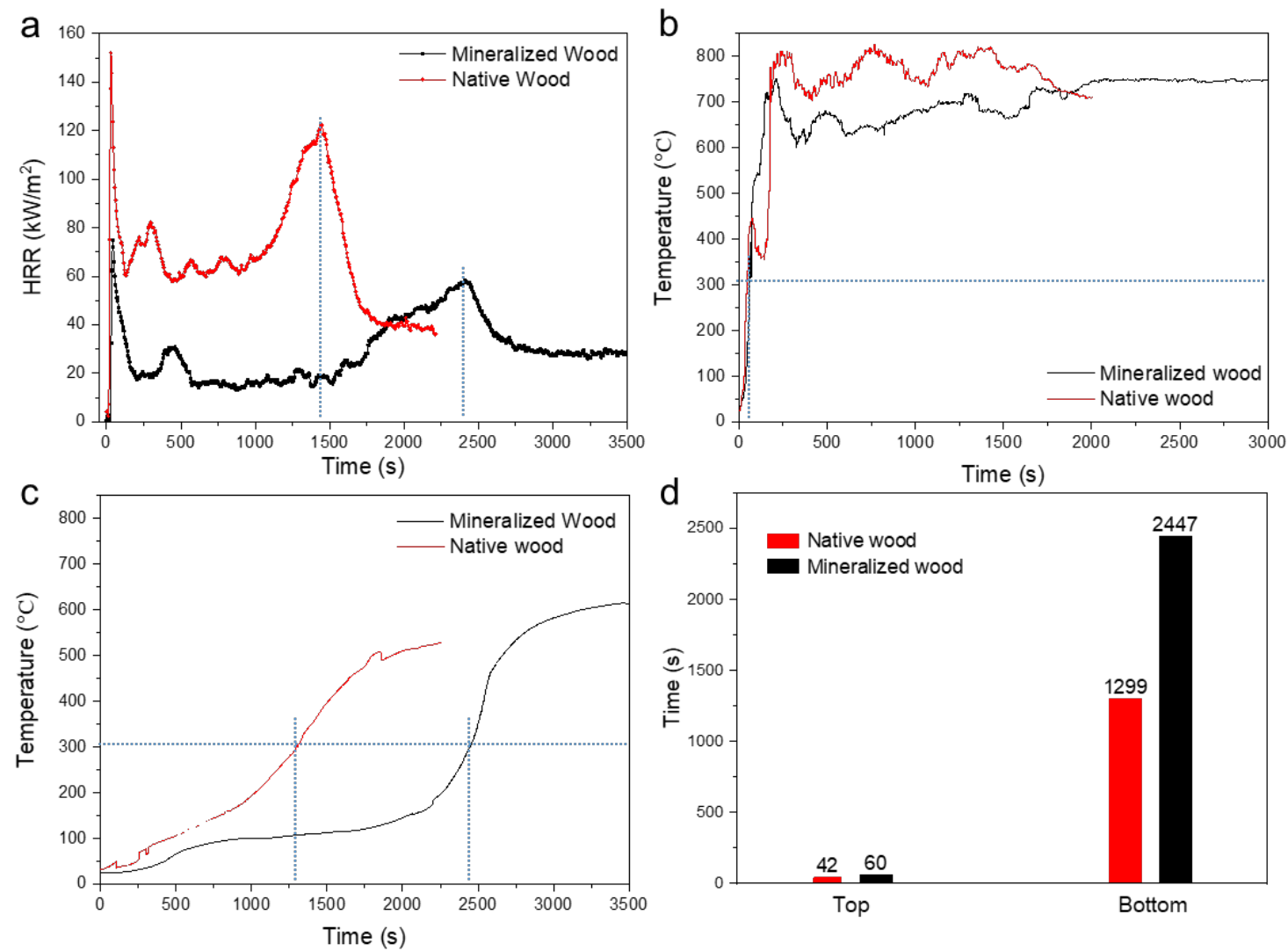

Figure 8. Heat release rate (HRR) of mineralized and native CLT panels (a); temperature evolution on the surface (b) and bottom (c) of the five-layer CLT panels; the time requires to reach $300{ }^{\circ} \mathrm{C}$ in the different positions of the CLT panel (d).

In contrast to native wood (Video S1), the mineralized wood is not ignitable when exposed to flame; only a charring process was observed (Video S2). The char layer is a fire barrier that retards the heat penetration in timber structure, and, therefore, protects the wood underneath. To investigate 
the fire barrier effect of the mineralized wood, we fabricated five-layer cross-laminated timber (CLT) for fire tests. Two thermocouples were installed on the surface, and at the bottom of the CLT, respectively, to follow the temperature change. The specimen was exposed to an igniter which provided a constant heat flux of $50 \mathrm{~kW} \cdot \mathrm{m}^{-2}\left(\mathrm{~T} \approx 750{ }^{\circ} \mathrm{C}\right)$. As shown in Figure 8a, there is a sharp HRR peak at about 30 s due to the surface ignition of the native wood. The second major HRR peak is located at about $1444 \mathrm{~s}$ because of the complete cracking of the five char layers. There are another three small HRR peaks between the 30s and 1444s because of the cracking of each char lay of the CLT panel. The CLT panel fabricated by struvite mineralized wood also exhibits two HHR peaks owing to the surface ignition and crack of the char layer. However, the HRR intensity was significantly suppressed, and the second peak is delayed by about 1000 s compared with the native wood. There was no apparent fire spread observed during the test. There is no obvious difference in the surface temperature of native and mineralized wood, which reached $300{ }^{\circ} \mathrm{C}$ in about 50 seconds (Figure 8b). The thermocouple installed at the bottom layered of the CLT detected different temperature curves between native and mineralized wood (Figure 8c). It takes 1299 seconds for the bottom part of the native wood fabricated CLT to reach $300{ }^{\circ} \mathrm{C}$, while it is 2447 second for the mineralized counterpart (Figure 8d) due to the fire barrier effect of the mineralized wood. The time for the bottom part to reach $300{ }^{\circ} \mathrm{C}$ is strongly correlated with the second HRR peak. $300{ }^{\circ} \mathrm{C}$ is considered to be a critical temperature, above which the main compound of wood will turn to char, and timber is no longer able to carry the load. Based on this assumption, the heat penetration rate of CLT fabricated using mineralized wood was calculated to be $0.6 \mathrm{~mm} / \mathrm{min}$, while the charring rate of CLT panel fabricated using native wood was calculated to be $1.2 \mathrm{~mm} / \mathrm{min}$. The average oxygen concentration during the cone calorimeter test is higher than that during the combustion test carried out in the furnace. Consequently, the heat penetration rate calculated from this study is higher than the typical charring rate of spruce wood measured by the furnace fire test. Furthermore, to verify that struvite mineralization is suitable for engineering application, we mineralized large size wood panels with a thickness of $50 \mathrm{~mm}$. The large size wood panels had similar weight gain compared to the small size samples used for mechanical analysis. The results indicate that the struvite mineralization is suitable for the modification of engineering wood.

\section{Conclusion}

In summary, we have carried out a systematic study on the mechanical properties, gluing properties, and thermal decomposition behavior of struvite mineralized wood. The influence of mineralization on the compression strength and Young's modulus strongly correlates with the loading direction. The paired T-test with native wood demonstrates that, along the fiber direction, the mineralization negatively influences the mechanical performance of wood by reducing the resistance to buckling. On the other hand, strength and modulus perpendicular to 
fiber direction is significantly increased, because the minerals in the cell lumen increase the resistance against cell wall buckling. The tension test in the longitudinal direction indicated no significant difference between the mineralized and native wood. The three-point bending test reveals a decrease in the strength and Young's modulus in mineralized wood by $8.1 \%$ and $5.6 \%$, respectively. The tensile shear test indicated that the mineralization has no or only minor influence on the compatibility of the wood samples with the tested commercial adhesives.

The thermal degradation of mineralized wood starts earlier (at $240{ }^{\circ} \mathrm{C}$ ) than in native wood (at $350{ }^{\circ} \mathrm{C}$ ). However, the total abundance of the evolved volatiles is drastically lower in the mineralized wood compared to native wood, which confirms the thermal resistance of the mineralized wood. Moreover, the pyrolysis products differ significantly between the native and mineralized wood. The native wood showed much more variable pyrolysis products from carbohydrates and aromatic compounds. However, mineralization resulted in the formation of one major compound of levoglucosenone, which is a highly dehydrated sugar. The decomposition of struvite mineral generates acidic phosphoric compounds, which catalyzes the formation of levoglucosenone (LGO) in the mineralized wood. The formation of such a highly dehydrated organic compound (LGO) promotes the char formation, which is responsible for the improved fire resistance. As a result, the charring rate of the CLT panel was reduced from $1.2 \mathrm{~mm} / \mathrm{min}$ to 0.6 $\mathrm{mm} / \mathrm{min}$. The results proved that the mineralization treatment is a modification that improves the fire resistance of wood but has a minor effect on the technologically relevant properties of solid wood.

\section{Supporting Information}

The Supporting Information is available free of charge on the ACS Publications website.

Specimen dimension, details about specimen densities and sizes, compression stress-strain cruves, 3D computer graphics, ion chromatograms, GC/MS analysis results (PDF).

Video S1: ignition behavior of native wood (MP4);

Video S2: ignition behavior of mineralized wood (MP4).

\section{Author Information}

Corresponding authors:

*Email: huguo@ethz.ch;

*Email: iburgert@ethz.ch.

${ }^{\#}$ Huizhang Guo and Merve Özparpucu contribute equally to this work.

\section{Acknowledgments}

This work was financially supported by Innosuisse Project 28473.1 PFIWIW. The authors thank Andreas Tenz for his valuable technical assistance for the pyrolysis experiments. The authors 
thank Milijana Jovic for her valuable technical assistance for the cone calorimeter experiment. The authors thank Sven Bucher for his assistance for the mechanical test. We acknowledge the Paul Scherrer Institut, Villigen, Switzerland for provision of synchrotron radiation beamtime at the TOMCAT beamline X02DA of the SLS.

\section{Reference}

1. Zabalza Bribián, I.; Valero Capilla, A.; Aranda Usón, A., Life cycle assessment of building materials: Comparative analysis of energy and environmental impacts and evaluation of the eco-efficiency improvement potential. Build. Environ. 2011, 46, 1133-1140, DOI 10.1016/j.buildenv.2010.12.002.

2. Goggins, J.; Keane, T.; Kelly, A., The assessment of embodied energy in typical reinforced concrete building structures in Ireland. Energy Build. 2010, 42, 735-744, DOI 10.1016/j.enbuild.2009.11.013.

3. Gustavsson, L.; Pingoud, K.; Sathre, R., Carbon Dioxide Balance of Wood Substitution: Comparing Concrete- and Wood-Framed Buildings. Mitig. Adapt. Strat. GL. 2006, 11, 667691, DOI 10.1007/s11027-006-7207-1.

4. Green, D. W.; Winandy, J. E.; Kretschmann, D. E., Mechanical properties of wood. Wood handbook: wood as an engineering material. Madison, WI: USDA Forest Service, Forest Products Laboratory, 1999. General technical report FPL; 1999, Vol. 113, pp:4.1-4.45. 5. Lowden, L. A.; Hull, T. R., Flammability behaviour of wood and a review of the methods for its reduction. Fire Sci. Rev. 2013, 2, Article 4, DOI 10.1186/2193-0414-2-4.

6. Wimmers, G., Wood: a construction material for tall buildings. Nat. Rev. Mater. 2017, 2, Article 17051, DOI 10.1038/natrevmats.2017.51

7. Horrocks, A. R.; Price, D.; Price, D., Fire retardant materials. Woodhead Publishing: 2001.

8. Shaw, S., Halogenated flame retardants: do the fire safety benefits justify the risks? Rev. Environ. Health 2010, 25, 261-306, DOI 10.1515/reveh.2010.25.4.261.

9. Hollingbery, L.; Hull, T. R., The fire retardant behaviour of huntite and hydromagnesite-A review. Poly. Degrad. Stabil. 2010, 95, 2213-2225, DOI 10.1016/j.polymdegradstab.2010.08.019.

10. Liu, F.; Zhu, W., Fire retardant intumescent coating for lignocellulosic materials. CA 02335565C, Decemenber 19, 2000.

11. Guo, B.; Liu, Y.; Zhang, Q.; Wang, F.; Wang, Q.; Liu, Y.; Li, J.; Yu, H., Efficient FlameRetardant and Smoke-Suppression Properties of Mg-Al-Layered Double-Hydroxide Nanostructures on Wood Substrate. ACS Appl. Mater. Interfaces 2017, 9, 23039-23047, DOI 10.1021/acsami.7b06803.

12. LeVan, S. L.; Tran, H. C. In The role of boron in flame-retardant treatments, First International Conference on Wood Protection with Diffusible Preservatives:... Nashville, Tennessee, November 28-30, 1990. Madison, WI: Forest Products Research Society, 1990; pp 39-41.

13. Araki, A.; Saito, I.; Kanazawa, A.; Morimoto, K.; Nakayama, K.; Shibata, E.; Tanaka, M.; Takigawa, T.; Yoshimura, T.; Chikara, H.; Saijo, Y.; Kishi, R., Phosphorus flame retardants in indoor dust and their relation to asthma and allergies of inhabitants. Indoor Air 2014, 24, 315, DOI 10.1111/ina.12054.

14. Song, J.; Chen, C.; Zhu, S.; Zhu, M.; Dai, J.; Ray, U.; Li, Y.; Kuang, Y.; Li, Y.; Quispe, N.; Yao, Y.; Gong, A.; Leiste, U. H.; Bruck, H. A.; Zhu, J. Y.; Vellore, A.; Li, H.; Minus, M. L.; Jia, Z.; 
Martini, A.; Li, T.; Hu, L., Processing bulk natural wood into a high-performance structural material. Nature 2018, 554, 224-228, DOI 10.1038/nature25476.

15. Gan, W.; Chen, C.; Wang, Z.; Song, J.; Kuang, Y.; He, S.; Mi, R.; Sunderland, P. B.; Hu, L., Dense, Self-Formed Char Layer Enables a Fire-Retardant Wood Structural Material. Adv. Funct. Mater. 2019, 29, Article 1807444, DOI 10.1002/adfm.201807444.

16. Fu, Q.; Medina, L.; Li, Y.; Carosio, F.; Hajian, A.; Berglund, L. A., Nanostructured Wood Hybrids for Fire-Retardancy Prepared by Clay Impregnation into the Cell Wall. ACS Appl. Mater. Interfaces 2017, 9, 36154-36163, DOI DOI:10.1021/acsami.7b10008.

17. Merk, V.; Chanana, M.; Gaan, S.; Burgert, I., Mineralization of wood by calcium carbonate insertion for improved flame retardancy. Holzforschung 2016, 70, 867-876, DOI 10.1515/hf-2015-0228.

18. Merk, V.; Chanana, M.; Keplinger, T.; Gaan, S.; Burgert, I., Hybrid wood materials with improved fire retardance by bio-inspired mineralisation on the nano- and submicron level.

Green Chemist. 2015, 17, 1423-1428, DOI 10.1039/c4gc01862a.

19. Jorge, F. C.; Pereira, C.; Ferreira, J. M. F., Wood-cement composites: a review. Holz Roh Werkst. 2004, 62, 370-377, DOI 10.1007/s00107-004-0501-2.

20. Wang, L.; Yu, I. K. M.; Tsang, D. C. W.; Yu, K.; Li, S.; Sun Poon, C.; Dai, J.-G., Upcycling wood waste into fibre-reinforced magnesium phosphate cement particleboards. Constr. and Build. Materials 2018, 159, 54-63, DOI 10.1016/j.conbuildmat.2017.10.107.

21. Wang, L.; Yu, I. K. M.; Tsang, D. C. W.; Li, S.; Poon, C. S., Mixture Design and Reaction Sequence for Recycling Construction Wood Waste into Rapid-Shaping Magnesia-Phosphate Cement Particleboard. Ind. Eng. Chem. Res. 2017, 56, 6645-6654, DOI 10.1021/acs.iecr.7b01175.

22. Walling, S. A.; Provis, J. L., Magnesia-Based Cements: A Journey of 150 Years, and Cements for the Future? Chem. Rev. 2016, 116, 4170-4204, DOI 10.1021/acs.chemrev.5b00463.

23. Côté, W. A., Chemical Composition of Wood. In Principles of Wood Science and Technology: I Solid Wood, Springer Berlin Heidelberg: Berlin, Heidelberg, 1968; pp 55-78.

24. Rowell, R. M.; Dietenberger, M. A., Thermal properties, combustion, and fire retardancy of wood. In: Second edition of the Handbood of wood Chemistry and Wood Composites, Rowell, R., Eds, by CRC Books, 2013, Vol. 6, pp:127-149.

25. Stevens, R.; van Es, D. S.; Bezemer, R.; Kranenbarg, A., The structure-activity relationship of fire retardant phosphorus compounds in wood. Polym. Degrad. Stabil. 2006, 91, 832-841, DOI 10.1016/j.polymdegradstab.2005.06.014.

26. Guo, H.; Luković, M.; Mendoza, M.; Schlepütz, C. M.; Griffa, M.; Xu, B.; Gaan, S.; Herrmann, H.; Burgert, I., Bioinspired Struvite Mineralization for Fire-Resistant Wood. ACS Appl. Mater. Interfaces 2019, 11, 5427-5434, DOI 10.1021/acsami.8b19967.

27. Yetilmezsoy, K.; Kocak, E.; Akbin, H. M.; Özçimen, D., Utilization of struvite recovered from high-strength ammonium-containing simulated wastewater as slow-release fertilizer and fire-retardant barrier. Environ. Technol. 2020, 41, 153-170, DOI

10.1080/09593330.2018.1491642.

28. Lam, F., Modern structural wood products. Prog. Struct. Eng. Mater. 2001, 3, 238245, DOI 10.1002/pse.79.

29. Brandner, R.; Flatscher, G.; Ringhofer, A.; Schickhofer, G.; Thiel, A., Cross laminated timber (CLT): overview and development. Eur. J. Wood Wood Prod. 2016, 74, 331-351, DOI 10.1007/s00107-015-0999-5. 
30. Zauner, M.; Stampanoni, M.; Niemz, P., Failure and failure mechanisms of wood during longitudinal compression monitored by synchrotron micro-computed tomography. Holzforschung 2016, 70, 179-185, DOI 10.1515/hf-2014-0225.

31. Bodig, J.; Jayne, B. A., Mechanics of wood and wood composites. Van Nostrand Reinhold New York: 1982.

32. Lakshmanan, C. M.; Hoelscher, H. E., Production of Levoglucosan by Pyrolysis of Carbohydrates. Pyrolysis in Hot Inert Gas Stream. Product R\&D 1970, 9, 57-59, DOI 10.1021/i360033a011.

33. He, J.; Liu, M.; Huang, K.; Walker, T. W.; Maravelias, C. T.; Dumesic, J. A.; Huber, G. W., Production of levoglucosenone and 5-hydroxymethylfurfural from cellulose in polar aprotic solvent-water mixtures. Green Chemist. 2017, 19, 3642-3653, DOI 10.1039/C7GC01688C.

34. Zhou, X.; Nolte, M. W.; Mayes, H. B.; Shanks, B. H.; Broadbelt, L. J., Experimental and Mechanistic Modeling of Fast Pyrolysis of Neat Glucose-Based Carbohydrates. 1.

Experiments and Development of a Detailed Mechanistic Model. Indust. Eng. Chemist. Res. 2014, 53, 13274-13289, DOI 10.1021/ie502259w.

35. Oyola-Rivera, O.; He, J.; Huber, G. W.; Dumesic, J. A.; Cardona-Martínez, N., Catalytic dehydration of levoglucosan to levoglucosenone using Brønsted solid acid catalysts in tetrahydrofuran. Green Chemist. 2019, 21, 4988-4999, DOI 10.1039/C9GC01526D.

36. Zandersons, J.; Zhurinsh, A.; Dobele, G.; Jurkjane, V.; Rizhikovs, J.; Spince, B.; Pazhe, A., Feasibility of broadening the feedstock choice for levoglucosenone production by acid pre-treatment of wood and catalytic pyrolysis of the obtained lignocellulose. J. Anal. Appl. Pyrolysis 2013, 103, 222-226, DOI 10.1016/j.jaap.2013.01.014.

37. Cao, F.; Schwartz, T. J.; McClelland, D. J.; Krishna, S. H.; Dumesic, J. A.; Huber, G. W., Dehydration of cellulose to levoglucosenone using polar aprotic solvents. Energy Environ. Sci. 2015, 8, 1808-1815, DOI 10.1039/C5EE00353A.

38. Trahanovsky, W. S.; Ochaoda, J. M.; Wang, C.; Revell, K. D.; Arvidson, K. B.; Wang, Y.; Zhao, H.; Chung, S.; Chang, S., A Convenient Procedure for the Preparation of Levoglucosenone and Its Conversion to Novel Chiral Derivatives. In Carbohydrate Synthons in Natural Products Chemistry, American Chemical Society: 2002; pp 21-31.

39. Marshall, J. A., An improved preparation of levoglucosenone from cellulose. 2008.

40. Sui, X.-W.; Wang, Z.; Liao, B.; Zhang, Y.; Guo, Q.-X., Preparation of levoglucosenone through sulfuric acid promoted pyrolysis of bagasse at low temperature. Bioresour. Technol. 2012, 103, 466-469, DOI 10.1016/j.biortech.2011.10.010.

41. Wang, Z.; Lu, Q.; Zhu, X.-F.; Zhang, Y., Catalytic Fast Pyrolysis of Cellulose to Prepare Levoglucosenone Using Sulfated Zirconia. ChemSusChem 2011, 4, 79-84, DOI 10.1002/cssc. 201000210.

42. Dobele, G.; Dizhbite, T.; Rossinskaja, G.; Telysheva, G.; Meier, D.; Radtke, S.; Faix, O., Pre-treatment of biomass with phosphoric acid prior to fast pyrolysis: A promising method for obtaining 1,6-anhydrosaccharides in high yields. J. Anal. Appl. Pyrolysis 2003, 68-69, 197211, DOI 10.1016/S0165-2370(03)00063-9.

43. Prywer, J.; Sieroń, L.; Czylkowska, A., Struvite Grown in Gel, Its Crystal Structure at 90 K and Thermoanalytical Study. Crystals 2019, 9, Article 89, DOI 10.3390/cryst9020089.

44. Ramlogan, M. V.; Rouff, A. A., An investigation of the thermal behavior of magnesium ammonium phosphate hexahydrate. J. Therm. Anal. Calorim. 2016, 123, 145-152, DOI 10.1007/s10973-015-4860-1.

45. Arias, M. E.; Rodríguez, J.; Pérez, M. I.; Hernández, M.; Polvillo, O.; González-Pérez, J. A.; González-Vila, F. J., Analysis of chemical changes in Picea abies wood decayed by 
different Streptomyces strains showing evidence for biopulping procedures. Wood Sci. Technol. 2010, 44, 179-188, DOI 10.1007/s00226-009-0282-1.

46. Hu, B.; Lu, Q.; Wu, Y.-t.; Xie, W.-I.; Cui, M.-s.; Liu, J.; Dong, C.-q.; Yang, Y.-p., Insight into the formation mechanism of levoglucosenone in phosphoric acid-catalyzed fast

pyrolysis of cellulose. J. Energ. Chem. 2020, 43, 78-89, DOI 10.1016/j.jechem.2019.08.001. 


\section{For Table of Contents Use Only}

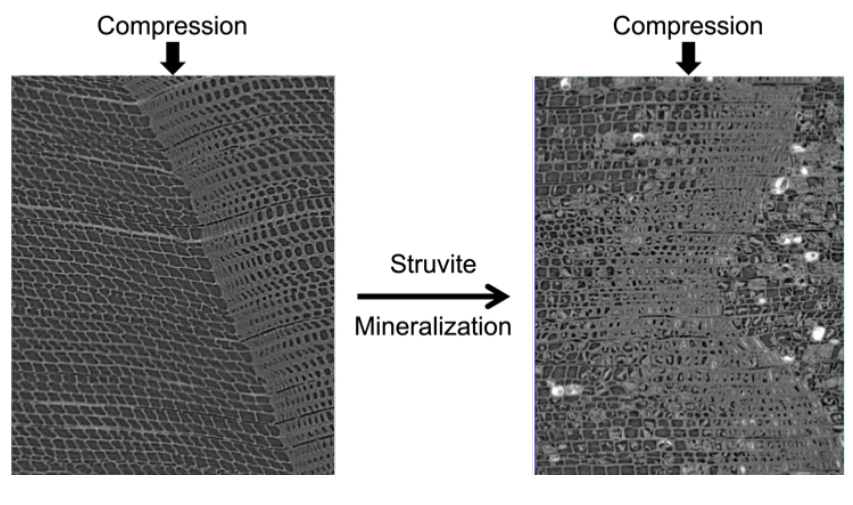

Struvite mineralization enables a more extensive use of wood in the construction sector as a substitute to less eco-friendly building materials. 